\title{
Chemical and Biological Control of Sclerotium rolfsii in Grapevine Nurseries
}

\author{
Helena A. Keyser and J.H.S. Ferreira \\ Viticultural and Oenological Research Institute (VORI), Private Bag X5026, 7600 Stellenbosch, Republic of South Africa.
}

Submitted for publication: February 1988

Accepted for publication: April 1988

Keywords: Sclerotium rolfsii, grapevine, control.

\begin{abstract}
Laboratory and glasshouse trials were conducted to determine the efficacy of Bacillus subtilis, Gliocladium virens and different concentrations of the fungicide quintozene (75\% WP) against Sclerotium rolfsii, causing death of grapevines in nurseries. Bacillus subtilis treatment considerably reduced the growth of $S$. rolfsii in vitro compared to the control. Quintozene at concentrations of $0,4,1,2,2,0$, and 3,2 $\mathrm{g}$ per litre mixed with PDA totally suppressed the growth of $S$. rolfsii. In the glasshouse $B$. subtilis gave poor control. $G$. virens reduced mortality of grapevine plants caused by $S$. rolfsii, while no mortality of plants occurred when vines or soil was treated with quintozene. Quintozene at a concentration of $2 \%$ can be recommended as control measure against $S$. rolfsii in nurseries.
\end{abstract}

Sclerotium rolfsii Sacc. is responsible for considerable economic loss on carrots (Gurkin \& Jenkins, 1985), beetroot (Agrihoti, Sen, \& Srivastrava, 1975), peanuts (Diomande \& Beute, 1977) and apples (Brown \& Hendrix, 1980). This fungus is also of economic importance on onions, cotton and carnations (Bot, Sweet, \& Hollings, 1986), and it is a serious problem on grapevines in callus trays as well as in nurseries (Marais, 1979). Marais (1983) found $S$. rolfsii infestation in 7,2\% of the grapevine nurseries in the Western Cape. During the $1984 / 85$ and the 1985/86 seasons several nurseries in the Wellington area suffered great losses in production due to $S$. rolfsii.

The fungus penetrates mainly at the graft unions, girdling the plants and eventually leads to the death of affected plants. The mycelia of $S$. rolfsii spread rapidly in soil and sclerotia (overwintering bodies) are produced in large numbers. Sclerotia may persist in the soil near the surface for several years (Punja, 1985).

The fungicide quintozene is registered for the control of $S$. rolfsii (Bot et al, 1986) and controls Sclerotinia minor (Brenneman, 1987) efficiently on various crops. Phillips (1986) found that Gliocladium virens parasitizes sclerotia of Sclerotinia sclerotiorum and sclerotia of $S$. rolfsii in the laboratory. Preliminary studies at the VORI indicated that Bacillus subtilis, isolated from vineyard soil, had an inhibitory effect on the mycelium growth of $S$. rolfsii in vitro. Wong and Hughes (1986) isolated a Bacillus specie from soil antagonistic to $S$. cepivorum on onion. B. subtilis is a well-known fungal antagonist and has been proven by several workers to be a successful biological control agent against different fungal diseases (Baker, Stavely, Thomas, Sasser \& MacFall, 1983; Vapinder \& Deverall, 1984; Baker \& Stavely, 1985).

In the present study the efficacy of quintozene, $G . v i$ rens and $B$. subtilis for the control of $S$. rolfsii was determined in laboratory and glasshouse experiments.

\section{MATERIALS AND METHODS}

\section{Laboratory studies}

Potato-dextrose-agar (PDA) was allowed to cool down after sterilisation to approximately $40^{\circ} \mathrm{C}$ and quintozene (75\% WP) added at concentrations of 0,4 ,
1,2, 2,0 and 3,2 g per litre. The solutions were mixed thoroughly, and five petri dishes poured for each conentration. Five PDA dishes without fungicide served as controls. A mycelium disc $(5 \mathrm{~mm} \phi)$ from a 3 -dayold PDA culture of $S$. rolfsii was placed on each petri dish and incubated at $25^{\circ} \mathrm{C}$. Radial growth of the fungus was measured in millimeters after 24,48 and 72 hours.

Bacillus subtilis was grown in liquid Czapekdox medium at $30^{\circ} \mathrm{C}$ for 3 days before $1,5 \mathrm{ml}$ of this bacterial suspension $(160000$ cells $/ \mathrm{ml})$ was added to $250 \mathrm{ml}$ sterile cooled PDA. The solution was thoroughly mixed and $10 \mathrm{ml}$ poured into each of five petri dishes. Mycelium discs of $S$. rolfsii were placed on each plate and incubated at $25^{\circ} \mathrm{C}$. Uninoculated Czapekdox medium in PDA served as controls. The radial growth of colonies was measured as mentioned above.

\section{Glasshouse studies}

Soil known to be suitable for $S$. rolfsii infestation was autoclaved (100 kPa for $15 \mathrm{~min})$ and placed in polyethylene planting bags $(30 \mathrm{~cm} \times 20 \mathrm{~cm} \varnothing)$. Ten Chenin blanc plants (grafted to 99 Richter) per treatment were taken from the callus room and planted in separate bags in such a way that the graft union was covered with soil.

Treatments:

1. S. rolfsii (100 sclerotia per bag) mixed with upper $100 \mathrm{~mm}$ of soil (control).

2. S. rolfsii $+40 \mathrm{ml}$ of a $B$. subtilis suspension $(160000$ cells/ml) mixed with upper $100 \mathrm{~mm}$ of soil.

3. S. rolfsii $+40 \mathrm{ml}$ of a $G$. virens suspension (144 500000 spores $/ \mathrm{ml}$, grown in malt liquid medium for 5 days) mixed with upper $100 \mathrm{~mm}$ of soil.

4. S. rolfsii $+0,4$ g quintozene ( $75 \%$ WP) mixed with upper $100 \mathrm{~mm}$ of soil

5. S. rolfsii + quintozene [Plants dipped in $20 \mathrm{~g}$ Quintozene (75\% WP) /l water for 10 seconds immediately before planting.]

Plants were kept in a glasshouse at $25^{\circ} \mathrm{C}$ and watered regularly.

Observations were made every day for 40 days after 
transplanting. In practice $S$. rolfsii causes mortality of plants for up to 3 weeks after transplant. Isolations were made from all dead plants to confirm the presence of $S$. rolfsii. At the end of the experiment isolations were made from all the plants that survived to determine if they were free of $S$. rolfsii.

\section{RESULTS AND DISCUSSIONS}

$B$. subtilis reduced the growth of $S$. rolfsii effectively on PDA when compared with the control (Table 1). This reduction in growth suggests that fungistatic material was produced by $B$. subtilis on PDA. According to Katz and Demain (1977) 66 different peptide antibiotics are elaborated by strains of $B$. subtilis. Quintozene totally suppressed growth of $S$. rolfsii on PDA at all the different concentrations used (Table 1).

\section{TABLE 1}

Effect of Bacillus subtilis and quintozene on the mean radial growth of $S$. rolfsii on potato-dextrose-agar (PDA) in laboratory studies.

\begin{tabular}{|l|c|c|c|}
\hline \multicolumn{1}{|c|}{ Treatment } & \multicolumn{3}{|c|}{ Growth $(\mathrm{mm})^{\mathrm{a}}$} \\
\cline { 2 - 4 } & $24 \mathrm{~h}$ & $48 \mathrm{~h}$ & $72 \mathrm{~h}$ \\
\hline PDA (Control) & 30 & 60 & 80 \\
PDA $+B$. subtilis & 7 & 12 & 15 \\
PDA $+0,4 \mathrm{~g}$ quintozene & 0 & 0 & 0 \\
$\begin{array}{l}\text { (75\% wp) } l \\
\text { PDA }+1,2 \mathrm{~g} \text { quintozene } \\
\text { (75\% wp) } / l\end{array}$ & 0 & 0 & 0 \\
PDA $+2,0 \mathrm{~g}$ quintozene \\
$\begin{array}{l}\text { 75\% wp) } / l \\
\text { PDA }+3,2 \mathrm{~g} \text { quintozene } \\
\text { (75\% wp) } / l\end{array}$ & 0 & 0 & 0 \\
\hline
\end{tabular}

${ }^{a}$ Average of five dishes.

In the glasshouse experiment $B$. subtilis had no effect on $S$. rolfsii and plant mortality was the same as in the control, indicating that $B$. subtilis possibly does not produce the fungistatic material in soil (Table 2).

\section{TABLE 2}

Effect of different chemical and biological treatments on the mortality of vines caused by Sclerotium rolfsii.

\begin{tabular}{|c|c|c|c|c|c|c|c|}
\hline \multirow[b]{2}{*}{ Treatment } & \multicolumn{7}{|c|}{ Mortality $(\%)^{c}$} \\
\hline & $18 \mathrm{~d}$ & $21 d$ & $25 d$ & $28 \mathrm{~d}$ & $32 d$ & $36 \mathrm{~d}$ & $40 d$ \\
\hline 1.S. rolfsii (control) ${ }^{\mathrm{a}}$ & 20 & 40 & 40 & 40 & 60 & 60 & 70 \\
\hline 2.S. rolfsii + B. subtilis ${ }^{\mathrm{a}}$ & 10 & 20 & 30 & 40 & 40 & 70 & 70 \\
\hline 3.S. rolfsii + G. virens ${ }^{\mathrm{a}}$ & 20 & 20 & 20 & 20 & 30 & 40 & 50 \\
\hline 4.S. rolfsii $+0,4 \mathrm{~g}$ quin- & & & & & & & \\
\hline tozene $75 \% \mathrm{WP}^{\mathrm{a}}$ & 0 & 0 & 0 & 0 & 0 & 0 & 0 \\
\hline 5.S. rolfsii + quintozene & 0 & 0 & 0 & 0 & 0 & 0 & 0 \\
\hline
\end{tabular}

a. The inoculum was mixed in the upper $100 \mathrm{~mm}$ of soil before planting.

b. $S$. rolfsii was mixed with the upper $100 \mathrm{~mm}$ of soil and plants dipped in $20 \mathrm{~g}$ quintozene/l water before planting.

c. Average of ten plants.
$G$. virens reduced plant mortality to a certain extent but control is not considered to be sufficient. $G$. virens is a mycoparasite and it was found by Philips (1986) that $G$. virens is able to parasitize sclerotia of $S$. rolfsii but has no effect on mycelia. When $G$. virens is given a longer time lapse to parasitize sclerotia of $S$. rolfsii before planting it may have a greater influence on plant survival and this will be investigated.

No plant mortality was observed with either of the quintozene treatments. Quintozene used as a dip and added to soil, effectively protected plants against $S$. rolfsii. Dipping of grafted vines in quintozene before callussing and again before planting in a nursery can be a practical way of controlling the disease in nurseries where $S$. rolfsii is a problem.

\section{LITERATURE CITED}

AGRIHOTI, V.P., SEN, C. \& SRIVASTRAVA, S.N., 1975. Role of fungi toxicants in the control of sclerotium root rot of sugarbeet, Beta vulgaris, L. Indian J. Exp. Biol. 13, 89-91.

BAKER, C.J. \& STAVELY, J.R., 1985. Biocontrol of bean rust by Bacillus subtilis under field conditions. Plant Disease 69, $770-772$.

BAKER, C.J., STAVELY, J.R., THOMAS, C.A., SASSER, M. \& MACFALL, J.S., 1983. Inhibitory effect of Bacillus subtilis on Uromyces phaseoli and on development of rust pustules on bean leaves. Phytopathology 73, 1148-1152.

BOT, J., SWEET, S. \& HOLLINGS, N., 1986. A guide to the use of pesticides and fungicides in the Republic of South Africa 31st ed. Directorate Agriculture Information, Private Bag X144, 0001 Pretoria, Republic of South Africa.

BRENNEMAN, T.B., 1987. Control of Sclerotinia blight of peanuts: Sensitivity and Resistance of Sclerotinia minor to Vinclozolin, Iprodione, Dicloran and PCNB. Plant Disease 71, 87-90.

BROWN, E.A. \& HENDRIX, F.F., 1980. Districution and control of Sclerotium rolfsii on apple. Plant Disease 64, 205-206

DIOMANDE, M. \& BEUTE, M.K., 1977. Comparison of soil plate fungicide screening and field efficacy in control of Sclerotium rolfsii on peanuts. Plant Disease 61, 408-412.

GURKIN, R.S. \& JENKINS, S.F., 1985. Influence of cultural practices, fungicides and inoculum placement on Southern Blight and Rhizoctonia crown rot of carrot. Plant Disease 67, 477-481.

KATZ, E. \& DEMAIN, A.C., 1977. The peptide antibiotics of $B a$ cillus: Chemistry biogenesis, and possible functions. Biol. Rev. 41, 449-474.

MARAIS, P.G., 1979. Fungi associated with root rot in vineyards in the Western Cape. Phytophylacitica 11, 65-68.

MARAIS, P.G., 1983. Phytophthora cinnamomi root rot of grapevines in South Africa. PhD Thesis. University of Stellenbosch, 7600 Stellenbosch. Republic of South Africa.

PHILLIPS, A.J.L., 1986. Factors affecting the parasitic activity of Gliocladium virens on sclerotia of Sclerotinia sclerotiorum and a note on its host range. Phytopathologische Zeitschrift. 116, 212-220.

PORTER, D.M. \& BEUTE, M.K., 1974. Sclerotinia blight of peanuts. Phytopathology 64, 263-264.

PUNJA, Z.K., 1985. The biology, ecology and control of Sclerotium rolfsii. Ann. Rev. Phytopathol. 23, 97-127.

VAPINDER, S. \& DEVERALL, B.J., 1984. Bacillus Subtilis as a control agent against fungal pathogens of citrus fruit. Trans. Br. Mycol. Soc. 83, 487-490.

WONG, W.C. \& HUGHES, I.K., 1986. Sclerotium cepivorum Berk in onion (Allium cepa L.) crops: isolation and characterization of bacteria antagonistic to the fungus in Queensland. J. Appl Bacteriol 60, 57-60. 